\title{
Nectandra ovatocaudata, a New Species of Lauraceae from Cajamarca, Peru
}

\author{
Jens G. Rohwer \\ Biozentrum Klein Flottbek und Botanischer Garten, Ohnhorststr. 18, D-22609 Hamburg, Germany. \\ rohwer@botanik.uni-hamburg.de
}

Abstract. A new species of Nectandra Rol. ex Rottb. (Lauraceae) from Cajamarca, Peru, is described and illustrated. Nectandra ovatocaudata Rohwer appears to be related to N. amazonum Nees, but differs in its leaf shape, in having a receptacle that is densely pubescent inside, and in its habitat.

Key words: IUCN Red List, Lauraceae, Nectandra, Peru.

With 114 species recognized in the most recent monograph (Rohwer, 1993), Nectandra Rol. ex Rottb. is the second largest genus of Lauraceae in the Neotropics (Ocotea Aubl. is estimated to have ca. 300 spp.). To my knowledge, only two new species have subsequently been added, $N$. roberto-andinoi (C. Nelson) C. Nelson (Nelson Sutherland, 2001) and $N$. tomentosa van der Werff (2003). Among the Neotropical Lauraceae, Nectandra is traditionally characterized by bisexual flowers with nine tetrasporangiate anthers in which the pollen sacs are arranged in a horizontal row or a shallow arc. In addition, the six tepals of the flower are horizontally spreading at anthesis, usually brilliant white on their adaxial side (as if covered with frost, due to a papillose surface), and somewhat fused at the base, both among themselves and with the filaments of the stamens and staminodes, so that the perianth and androecium drop off as a ring after anthesis. Very often, but not in every species, the anthers are papillose as well and distinctly prolonged beyond the pollen sacs. This combination of characters makes Nectandra relatively easy to recognize when in flower, but nevertheless preliminary data (Chanderbali et al., 2001; J. G. Rohwer, unpublished) suggest that it is not monophyletic, with the 21 species of the $N$. coriacea (Sw.) Griseb. group sensu Rohwer (1993) forming a clade separate from the remaining species.

When looking through recently collected material, Henk van der Werff (Missouri Botanical Garden, St. Louis) found some specimens that would not fit any of the species described in the most recent monograph (Rohwer, 1993), and so he asked for my opinion about these. Some of them could be regarded as extreme forms of variable species complexes, and in some the available material was not yet adequate for a description, but two collections representing a new species appeared to be both distinctive and complete enough for description. This species is described below.

Nectandra ovatocaudata Rohwer, sp. nov. TYPE: Peru. Cajamarca: Prov. San Ignacio, Distr. San José de Lourdes, Poblado Los Llanos, bosque alrededor de la comunidad, $05^{\circ} 06^{\prime} 16^{\prime \prime} \mathrm{S}$, $078^{\circ} 51^{\prime} 11^{\prime \prime} \mathrm{W}, 1860 \mathrm{~m}, 10$ Oct. 2006 (fl.), J. Perea \& V. Flores 2815 (holotype, MO-6150301; isotypes, HBG, MO-6150300, USM not seen). Figure 1.

Species ut videtur inter Nectandram amazonum Nees et $N$. laurel Klotzsch ex Nees intermedia, sed a hac indumento foliorum abaxialiter brevi adpressoque et venulis tertiariis minus prominentibus, ab illa foliis ad basem late rotundatis et receptaculo intus dense pubescente, ab ambabus floribus minoribus differt.

Small tree, 5-6 m (according to type label); twigs roundish-angular, $5 \mathrm{~cm}$ below terminal bud $2.3-3$ $\mathrm{mm}$ diam., initially densely covered with short $(<0.2$ $\mathrm{mm}$ ), appressed, brownish trichomes pointing toward branch apices, this pubescence on older parts of the twig largely worn off; terminal buds elongate, densely covered with similar indument. Leaves alternate or in the distal, flowering parts of the twigs often subopposite; petioles $15-20 \times 1.3-3 \mathrm{~mm}(10-15 \times$ $1-1.5 \mathrm{~mm}$ in the inflorescence region), roundish below, flat to slightly canaliculate above, with an indument as on twigs; lamina (ovate to) elongateovate to lanceolate, $(7.5-) 12-16 \times(2.5-) 4-7.5(-9)$ $\mathrm{cm}, 1.8-3.5$ times longer than wide, widest $25 \%-$ $40 \%$ from the base, blade base obtuse to broadly rounded, tip tapering toward a mostly rather long but not distinctly separated acumen, margin flat; blade midrib prominent below, level to slightly impressed above; secondary veins 6 to 8 on each side of the midrib, diverging at $45^{\circ}-55^{\circ}$, curved toward the tip, distinctly raised below, level above, tertiary venation \pm scalariform, level to very slightly raised on both sides; blade indument consisting of short $(<0.2 \mathrm{~mm})$ appressed hairs pointing toward the leaf tip, above 


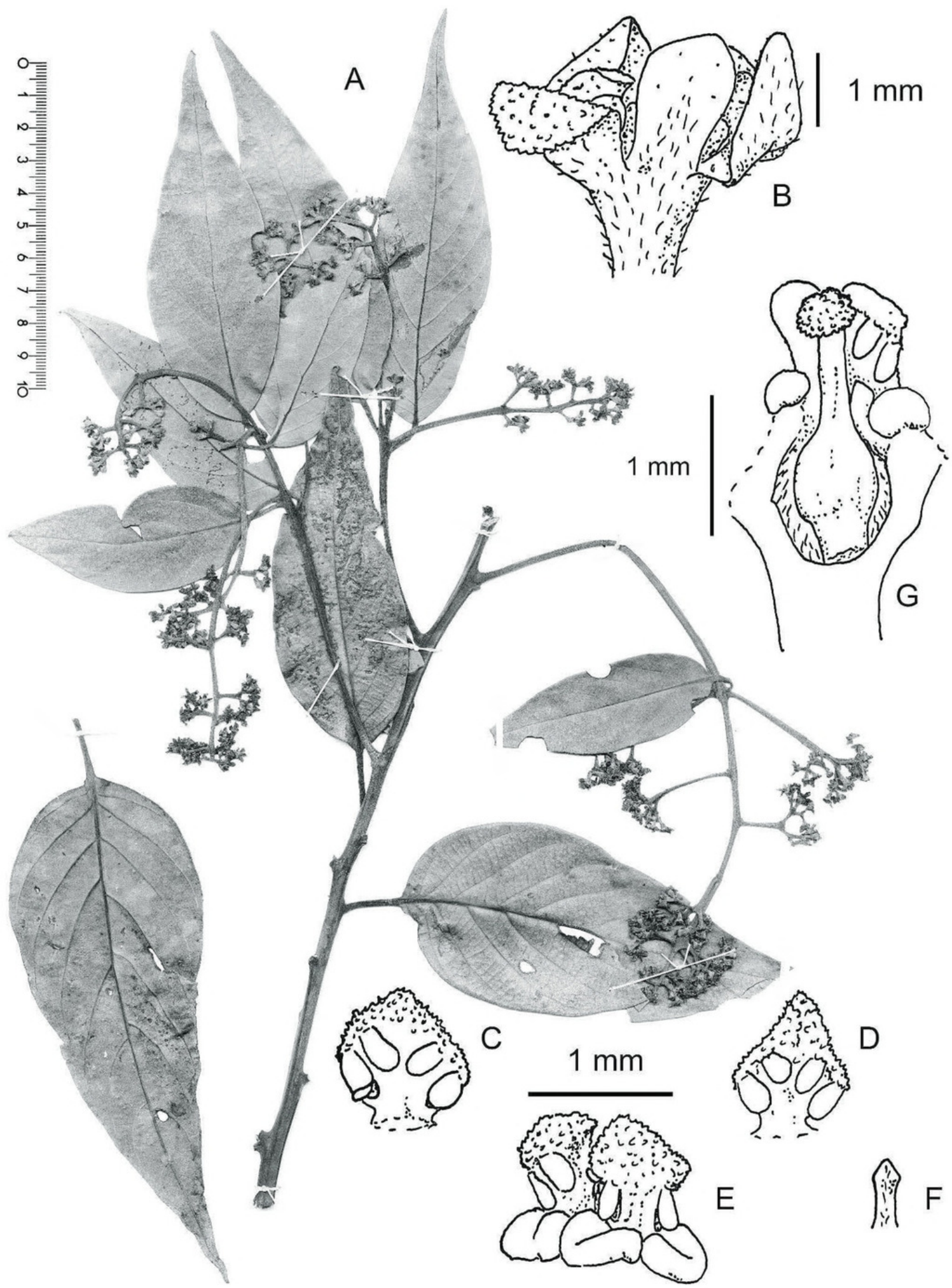

Figure 1. Nectandra ovatocaudata Rohwer. -A. Habit as seen in the photo of the holotype J. Perea \& V. Flores 2815 (MO). - B. Dried flower. - C. Stamen of the first androecial whorl, seen from the adaxial side. - D. Stamen of the second androecial whorl, seen from the adaxial side. - E. Two stamens of the third androecial whorl, lateral view (at left) and seen from the abaxial side (at right). - F. Staminode of the fourth androecial whorl, seen from the adaxial side. - G. Receptacle, cut open (semischematic), with ovary, two stamens of the third androecial whorl and a staminode evident between the ovary and the stamen on the right. Illustrations in $\mathrm{B}-\mathrm{G}$ taken from the holotype. 
initially moderately dense but still inconspicuous, quickly glabrescent, below initially moderately dense to dense, quickly becoming sparser and rather inconspicuous. Inflorescences thyrsoid, in the axils of distal foliage leaves, 5-11 cm long (one of them 20 $\mathrm{cm}$, with frondose bracts at the first branching), 1.31.8(-2.3) $\mathrm{mm}$ thick at the base, with an indument as on the twigs throughout, distally also with a few slightly longer and more ascending hairs, peduncle $3-5.5 \mathrm{~cm}$, lateral branches cymose, $(2$ to $) 4$ to 6 below a terminal cluster of 3 or 4 cymes, branched 1 to 3 times; pedicels $0.6-1.5 \times 0.6-0.8 \mathrm{~mm}$. Flowers white (according to type label), bisexual, ca. 5-6 mm diam.; tepals elliptic, ca. $2.2-2.5 \times 1.3-1.8 \mathrm{~mm}$, papillose on adaxial side, outer tepals pubescent on abaxial side, inner tepals usually slightly smaller, abaxially pubescent only in the basal triangle that is not covered by the outer tepals in bud; fertile stamens 9 , ca. $1 \mathrm{~mm}$, tetrasporangiate, pollen sacs arranged in a shallow are in the basal $2 / 3$ of the anther, the apical portion sterile, papillose, filaments extremely short, indistinct, in the outer whorls abaxially adnate to the tepals, stamens of the first whorl \pm ovate, ca. $1 \mathrm{~mm}$ wide, in the second whorl more trullate and slightly narrower, in the third whorl abaxially with a pair of glands at the base, apically obtuse to broadly rounded; staminodes (as a fourth androecial whorl) largely hidden between the glands, ca. $0.5 \mathrm{~mm}$ long, slightly thickened at the tip, fused with the adjacent stamens at the base; pistil ca. $2 \mathrm{~mm}$, glabrous, ovary ca. $1 \mathrm{~mm}$, ellipsoid, almost completely enclosed by the receptacle and the fused stamen bases; receptacle urceolate, densely pubescent inside. Fruit unknown.

Etymology. Nectandra ovatocaudata is named for its unusual leaf shape. The larger leaves have a more or less rounded base, as in ovate leaves, but they taper very gradually toward a rather long tip. The widest leaf of the paratype, however, has only a short acumen.

Habitat and distribution. Nectandra ovatocauda$t a$ is found in tropical montane forest and its degraded remnants, and possibly (according to the type label) in swamp as well. The species is so far only known from the province of San Ignacio, Cajamarca, Peru.

IUCN Red List category. Since Nectandra ovatocaudata is known from only two collections from a single province in Peru, its conservation status cannot be adequately assessed at this time. It is considered Data Deficient (DD), according to IUCN (2001) criteria.
Discussion. Nectandra ovatocaudata is a typical Nectandra, with anthers showing an obtuse to triangular, papillose sterile tip. It is described here with some hesitation, since many typical Nectandra species are linked by occasional intermediate collections (see Rohwer, 1993). Here, however, a considerable geographical distance and a habitat difference support its recognition as a separate species. Using the key from Rohwer (1993), it would most likely be identified as $N$. amazonum, a species from seasonally inundated Amazonian lowland forests, below $200 \mathrm{~m}$ altitude. Although the leaf shape is quite variable in $N$. amazonum, it never has such a broadly rounded leaf base as in $N$. ovatocaudata. In addition, $N$. amazonum usually has larger flowers (6.5-10 $\mathrm{mm}$ diam.), and its receptacle is glabrous inside. Broadly rounded leaf bases and a receptacle that is densely pubescent inside are sometimes found in the Andean N. laurel. In that species, however, the indument on the lower leaf surface is usually longer $(0.4-0.8 \mathrm{~mm})$, denser, more feltlike, and more persistent. Even in the least pubescent collections the trichomes do not show a parallel orientation, as in $N$. ovatocaudata. In addition, the leaves of $N$. laurel show a much more prominent tertiary venation, and its flowers are generally larger, usually $9-14 \mathrm{~mm}$ in diameter.

Paratype. PERU. Cajamarca: Prov. San Ignacio, Distr. Huarango, Poblado Selva Andina, $05^{\circ} 03^{\prime} 50^{\prime \prime} \mathrm{S}$, 078 $43^{\prime} 19^{\prime \prime W}, 2378$ m, 21 Aug. 2007 (fl.), J. Perea, E. Becerra, A. Peña \& J. Díaz 3607 (HBG, MO).

Acknowledgments. I thank the curator of the Missouri Botanical Garden herbarium (MO) for sending the specimens on loan, and Henk van der Werff (MO) for leaving the description of this new species to me.

\section{Literature Cited}

Chanderbali, A. S., H. van der Werff \& S. S. Renner. 2001. Phylogeny and historical biogeography of Lauraceae: Evidence from the chloroplast and nuclear genomes. Ann. Missouri Bot. Gard. 88: 104-134.

IUCN. 2001. IUCN Red List Categories and Criteria, Version 3.1. Prepared by the IUCN Species Survival Commission. IUCN, Gland, Switzerland, and Cambridge, United Kingdom.

Nelson Sutherland, C. H. 2001. Plantas descritas originalmente de Honduras y sus nomenclaturas equivalentes actuales. Ceiba 42: 1-71.

Rohwer, J. G. 1993. Lauraceae: Nectandra. Fl. Neotrop. 60. New York Botanical Garden, Bronx.

van der Werff, H. 2003. New taxa of Lauraceae from South America. Novon 13: 337-357. 


\section{$2 \mathrm{BHL}$ Biodiversity Heritage Library}

Rohwer, J. G. 2012. "Nectandra ovatocaudata, a New Species of Lauraceae from Cajamarca, Peru." Novon a journal of botanical nomenclature from the Missouri Botanical Garden 22(2), 220-222. https://doi.org/10.3417/2011099.

View This Item Online: https://www.biodiversitylibrary.org/item/196082

DOI: https://doi.org/10.3417/2011099

Permalink: https://www.biodiversitylibrary.org/partpdf/218562

\section{Holding Institution}

Missouri Botanical Garden, Peter H. Raven Library

\section{Sponsored by}

Missouri Botanical Garden

\section{Copyright \& Reuse}

Copyright Status: Permission to digitize granted by rights holder Rights: https://www.biodiversitylibrary.org/permissions

This document was created from content at the Biodiversity Heritage Library, the world's largest open access digital library for biodiversity literature and archives. Visit BHL at https://www.biodiversitylibrary.org. 